\author{
Vol: 3, Issue: 2 \\ February/2022 \\ DOI: http://dx.doi.org/10.47742/ijbssr.v3n2p1 \\ https://ijbssrnet.com/index.php/ijbssr
}

\title{
Nigeria's Perpetual Underdevelopment and Theory of Development Policy
}

Mashhud A. FASHOLA
Department of Economics
Faculty of Social Sciences
Lagos State University
Ojo, Lagos, Nigeria

\section{A R T I C L E I N F O}

Article history:

Received: $\quad 28$ Jan 2022

Revised: $\quad 20$ Feb 2022

Accepted: $\quad 25$ Feb 2022

Publication: Feb-28, 2022

DOI: $10.47742 / i j b s s r . v 3 n 2 p 1$

https://creativecommons.org/licenses/by/4.0/

\section{A B S T R A C T}

The paper revealed how Nigeria has remained perpetually underdeveloped by various development indicators. To explain Nigeria's perpetual underdevelopment, the paper presented a Structural Theory of Development Policy. The theory postulates an interrelationship among four components of any economic system, comprising policy instruments (vector $\boldsymbol{x}$ ), external exogenous variables (vector $\boldsymbol{u}$ ), target and non-target endogenous variables (vectors $y$ and $z$ ), impacting welfare function $w(y)$, as illustrated below:

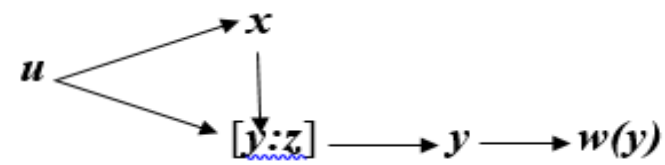

The theory elucidates perpetual underdevelopment by the following obstacles:

(i) Perverted articulation of development objectives

(ii) Deficient knowledge of the economic system

(iii) Excessive vulnerability to external factors

(iv) Limited capacity for policy implementation

The resolution of these obstacles was discussed. However, the deficient knowledge of the economic system was considered the critical factor for extensive empirical analysis. A classical illustration is the foreign-exchange excess-demand theory, empirically proven to be a false paradigm, inapplicable to the Nigerian economy characterized by overwhelming dependence on primary commodity exports, price and income inelastic demand for goods and services, double-digit inflation rate, severe political instability, and unbridled corruption fuelling capital flight. Comprehensive econometric analysis for Nigeria negated the foreign exchange excess demand theory in all its ramifications, justifying the need for foreign exchange market regulation.

Keywords: Underdevelopment, Sustainable development, Development policy

\section{INTRODUCTION} Countries

1.1 Perpetual Underdevelopment in Less-developed

Some development economists had predicted that lessdeveloped countries of the Third World would remain perpetually underdeveloped on account of their unfavorable external dependence, especially on their former Colonial Masters, based on neo-classical dependence theories, false paradigms, or centerperiphery development models (Weisskopf, 1972; Galtung, 1972; Baran, 1975; Leys, 1975; Griffin and Gurley, 1985; Singer, 1970; Lewellen, 1995; Chang, 2002; Olutayo, 2007). Challenging these positions for the explanation of underdevelopment are the arguments of Neoclassical Counterrevolution that the major cause of unrelenting underdevelopment is the absence of marketfriendly policies (Little, 1982; Bauer, 1984; Lal, 1985; among others) and the contentions of Public Choice Theory identifying unbridled corruption of public office holders as the major cause (Buchanan, 1954; Grindle \& Thomas, 1991; among others). An attempt at objective review and reconciliation of the contending schools of thought concluded that the various theories have their strengths and weaknesses and lessons to offer for relevant aspects of well-formulated government policies (Todaro \& Smith, 2015). There is no doubt that most countries of the Third World have remained perpetually underdeveloped, especially subSaharan Africa, despite multifarious development policies and external development aids. In UNDP's 2019 Human Development Report, 62 countries were in the first category of Very High Human Development, 54 in the second category of High Human Development, 37 in the third category of Medium Human Development, and 36 in the fourth category of Low Human Development. Sub-Saharan Africa (excepting South Africa) accounted for 28 out of 36 countries of low human development category, and 9 out of 37 countries of medium human development category. The World Bank (2019) classified countries by categories of Low Income (below \$1,035), Low Medium Income $(\$ 1,036$ to $\$ 4,045)$, Upper Medium Income $(\$ 4,046$ to $\$ 12,535)$, and High Income (above $\$ 12,535$ ). Twenty countries of Sub-Saharan Africa belong to the Low Income, fifteen belong to Low Medium Income, while only three small countries with populations below 3 million belong to Upper 


\title{
International Journal of Business and Social Science Research
}

\author{
Vol: 3, Issue: 2 \\ February/2022 \\ DOI: http://dx.doi.org/10.47742/ijbssr.v3n2p1 \\ https://ijbssrnet.com/index.php/ijbssr
}

Medium Income. If we consider the 22 sizable sub-Saharan Sahara Africa with some having negative growth. These paint a African countries, those with a population above 10 million, 13 of graphic picture of not only the perpetual underdevelopment of them belong to the Low Income while nine belong to Low less-developed countries of sub-Saharan Africa but also of the Medium Income in 2019, indicating perpetual underdevelopment widening development gap.

for well over half a century after their independence.

This paper adopts an ideologically neutral analysis of the Another way of assessing the persistent root causes of perpetual underdevelopment based on underdevelopment in sub-Saharan Africa is by comparing their a Structural Theory of Development Policy. The Structural per capita GDP with those of selected developed countries. Per Theory of Development Policy presented here is an extension of capita GDP for the USA was 29 times the average for sub-Saharan Tinbergen's Theory of Economic Policy (Tinbergen, 1978). It Africa in 1980 and has gone up to 81 times in 2019, as reflected depicts the basic structure and dynamics of any economic system in Table 1. The annual growth rate of US per capita GDP between and the adequacy and development impact of policy instruments, 1980 and 2019 was $4.3 \%$ compared with $1.4 \%$ on average for the taking into account the impact of external exogenous variables on sub-Sahara African countries (excluding South Africa). In Table the economy. Through the theory, the basic obstacles to the 1 , the average growth of GDP per capita for the six developed effectiveness of development policies and hence perpetual countries is $3.7 \%$ as compared with the average of $1.4 \%$ for sub- underdevelopment are deduced.

Table 1

Per Capita Gdp of Selected Developed Countries And Sub-Sahara African Countries

\begin{tabular}{|c|c|c|c|}
\hline COUNTRY & $\begin{array}{l}\text { GDP per Capita } \\
\text { US\$ } 1980\end{array}$ & $\begin{array}{c}\text { GDP per Capita US\$ } \\
2019\end{array}$ & $\begin{array}{l}\text { Growth rate per } \\
\text { annum } \%\end{array}$ \\
\hline 1. UNITED STATES OF AMERICA & 12,576 & 65,118 & 4.31 \\
\hline 2. GERMANY & 11,070 & 46,259 & 3.73 \\
\hline 3. CANADA & 11,239 & 46,195 & 3.69 \\
\hline 4. UNITED KINGDOM & 10,672 & 42,300 & 3.59 \\
\hline 5. FRANCE & 13,112 & 40,494 & 2.93 \\
\hline 6. JAPAN & 9,339 & 40,247 & 3.82 \\
\hline AVERAGE & 11,335 & 46,769 & 3.68 \\
\hline \multicolumn{4}{|l|}{ SUB-SAHARA AFRICA* } \\
\hline 1. BENIN & 463 & 1,219 & 2.51 \\
\hline 2. BURKINA FASO & 291 & 775 & 2.54 \\
\hline 3. CAMEROON & 929 & 1,498 & 1.23 \\
\hline 4. CHAD & 167 & 710 & 3.78 \\
\hline 5. CONGO D.R. & 2,389 & 545 & -3.72 \\
\hline 6. ETHIOPIA & 215 & 876 & 3.67 \\
\hline 7. GHANA & 2,496 & 2,202 & -0.32 \\
\hline 8. IVORY COAST & 1,258 & 2,286 & 1.54 \\
\hline 9. KENYA & 642 & 1,817 & 2.70 \\
\hline 10. MADAGASCAR & 462 & 522 & 0.31 \\
\hline 11. MALAWI & 327 & 412 & 0.59 \\
\hline 12. MALI & 286 & 891 & 2.96 \\
\hline 13. MOZAMBIQUE & 445 & 492 & 0.26 \\
\hline 14. NIGER & 461 & 555 & 0.48 \\
\hline 15. NIGERIA & 639 & 2,230 & 3.26 \\
\hline 16. RWANDA & 271 & 802 & 2.82 \\
\hline 17. SENEGAL & 620 & 1,447 & 2.20 \\
\hline 18. SIERRA LEONE & 511 & 505 & -0.03 \\
\hline 19. SUDAN & 530 & 442 & -0.46 \\
\hline 20. TANZANIA & 398 & 1,122 & 2.69 \\
\hline 21. UGANDA & 512 & 777 & 1.08 \\
\hline 22. ZAMBIA & 719 & 1,291 & 1.51 \\
\hline AVERAGE & 683 & 1,064 & 1.44 \\
\hline
\end{tabular}

Source: IMF Estimate for 1980; World Bank (data.worldbank.org) for 2019 GDP per capita.

* The selected 22 countries are those with a population above 10 million in 2019.

1.2 A Pragmatic Approach to the Concept of per head, has given way to new concepts and definitions Development incorporating socially desirable changes in institutions, cultures,

The traditional definition of development that attitudes, income distribution, human rights, freedom of choice, emphasized the long-term sustained increase in national income quality of life, and individual "capabilities", in addition to 


\title{
International Journal of Business and Social Science Research
}

\author{
Vol: 3, Issue: 2 \\ February/2022 \\ DOI: http://dx.doi.org/10.47742/ijbssr.v3n2p1 \\ https://ijbssrnet.com/index.php/ijbssr
}

sustained growth in per capita income (Seers, 1969; Goulet, 1971; Sen, 1985, 1999; Todaro \& Smith, 2015, among others). This comprehensive view of development is also shared by the World Bank (World Development Report, 1991:4) that "the challenge of development is to improve the quality of life", and that although improving the quality of life calls for higher income, the challenge of development is much more than that, as "it encompasses as ends in themselves better education, higher standards of health and nutrition, less poverty, a cleaner environment, more equality of opportunity, greater individual freedom, and a richer cultural life".

To emphasize the comprehensiveness and long-term nature of development, the concept of sustainable development came into vogue. The term "sustainable development" was first formally conceptualized by Brundtland Commission as "development that meets the needs of the present without compromising the ability of future generations to meet their own needs" (United Nations, 1987). Moreover, the dimensions of environmental sustainability, ecological harmony, long-term dynamic efficiency of economic activities, positive social change, and cultural integrity have been incorporated into the concept of sustainable development (Barbier. 1987; Pearce, et al, 1989; Dasgupta, 2007; UNDP, 2011; Todaro \& Smith, 2015; among others).

However, for a critical analysis of underdevelopment, sustainable development is here expressed in practical terms to simplify the abstract, interwoven, and comprehensive dimensions of sustainable development in the following eight explicit factors of social concern:

(i) Economic Growth and Structural Transformation, whereby economic development is genuinely reflected in the positive structural transformation of the economy (Kuznets 1971, 1973; Syrquin et al, 1984);

\section{(ii) Population growth and rural-urban} distribution relative to land resources and growth of agriculture, infrastructure, and housing, compounded by urban-biased development policies, with long-term consequences for continual migration and choking urbanization, environmental degradation, insecurity, and political instability;

(iii) Widening income inequality and dysfunctional market imperfections that prevent substantial sections of the population from benefiting from economic growth, thus resulting in rising poverty index, joblessness, insecurity, and political instability;

(iv) Extent of economic, technological, and political dependence of the less-developed country rendering the country highly vulnerable to external factors and creating persistent economic and political instability;

(v) Imbalance in the inter-dependent multi-sector development, especially between the traded sectors (manufacturing, mining, agriculture) and the non-traded (energy, transportation, security, housing);

(vi) Rapidity of the inflation rate, which causes prices of domestic products to rise much faster than those of developed countries, thus decreasing the industrial competitiveness of less-developed countries, perpetuating underdevelopment, exchange rate instability, and widening development gap;

(vii) Environmental pollution and degradation, owing to the divergence between social and private economic interests, resulting in the continual ground, water, and atmospheric pollution, deforestation, and environmental non-sustainability of development.

(viii) Intellectual, moral, and social aspects of development: Long-term economic growth cannot lead to sustainable development if political leadership and the people become more fraudulent and inhumane, and where domestic violence, alcoholism, drug abuse, juvenile delinquency, and terrorism are worsening.

Section 2 establishes evidence of perpetual underdevelopment in Nigeria. Section 3 presents the Structural Theory of Development Policy and expounds therewith the fundamental factors responsible for the perpetual underdevelopment. Section 4 constitutes the summary.

\section{PERPETUAL UNDERDEVELOPMENT IN NIGERIA}

Through a variety of unassailable development indicators, it is shown that extreme underdevelopment has persisted in Nigeria for over six decades.

In respect of indicators of structural transformation in economic development, Nigeria has remained at the bottom of underdevelopment because the manufacturing sector accounts for $3 \%$ to $7 \%$ of export earnings from 1981 to 2019, while the proportion of export earnings from primary commodities (largely crude oil) has fluctuated between $93 \%$ to $98 \%$ during the same period (CBN Statistical Bulletin, 2020). The average figure for less-developed countries is around $30 \%$ export earnings from manufactured goods and $70 \%$ from primary commodities. For developed countries, on the other hand, it is around $70 \%$ export earnings from manufactured goods and $30 \%$ for primary commodities. Furthermore, the GDP share of the manufacturing sector rather than rise in Nigeria has generally been falling from 1981 to date. From $29.9 \%$ in 1981, the GDP share of the manufacturing sector fell to $11.7 \%$ in 2000 and $9.1 \%$ in 2019 . A corresponding indicator of industrial development is the relative growth of infrastructural services of energy and transportation sectors, which lay the foundation for economic development. The energy sector, especially electricity and gas, and the transportation sector, especially the railway and pipelines, have performed relatively woefully. The GDP share of electricity and gas has remained miserably low, at $0.03 \%$ from 1981 to 2000 , and thereafter rose to $0.4 \%$ in 2019 . The share of railway and pipelines as the efficient means of transportation for a large country like Nigeria fell from $0.05 \%$ in 1981 to $0.0002 \%$ in 2000 and rose marginally to $0.0003 \%$ in 2019 .

The use of GDP per capita to measure economic development can be misleading for less-developed countries characterized by a double-digit inflation rate. Inter-temporal comparison of GDP will be a Herculean task for statistical authorities to accurately compute inflation rates for innumerable goods and services for diverse rural and urban areas to generate GDP deflators for converting GDP components at current prices 


\title{
International Journal of Business and Social Science Research
}

\author{
Vol: 3, Issue: 2 \\ February/2022 \\ DOI: http://dx.doi.org/10.47742/ijbssr.v3n2p1 \\ https://ijbssrnet.com/index.php/ijbssr
}

to constant base-year prices. Despite the shortcomings of its calculations, the GDP growth rates in Nigeria have been unimpressive. Although the GDP growth averaged 3.5\% from 1981 to 2019 , the growth fluctuated from 1.4\% 1981-2000 period to $7.9 \%$ 2000-2010 period and 3.0\% 2010-2019 period (CBN, Statistical Bulletin, 2020). With the population growth rate of 2.5 to $3 \%$, the GDP average growth rate of $1.4 \%$ during the 1981-2000 period implies that per capita GDP fell throughout the two decades. Such a fall would have resulted in irreversible nutritional calamities for millions of Nigerian children. From 1981 to 2000, the population of Nigeria rose from 74.4 to 122.3 million, indicating that the 50 million increase aged below 19 years would largely be children belonging to the poorest groups.

Apart from indicators of economic structural transformation, the following development indicators relevant to the key explicit factors of sustainable development have been selected based on their comprehensiveness and data availability:

(i) UNDP Human Development Index (HDI); (ii) Poverty index reflecting the living standards and income inequality;

(iii) Child Mortality Rate and Maternal Mortality Ratio;

(iv) Food Export-Import Ratio reflecting food security and long-term self-reliance;

(v) Indicators of Environmental Pollution and Degradation

\subsection{Assessment by Human Development Index (HDI)}

Table 2(a) shows the trend of the Human Development Index (HDI) for Nigeria in comparison with the average for SubSahara Africa, with developing countries of Medium Human Development, and with the World average. Nigeria's HDI was slightly above the sub-Sahara African average in 2005 but fell below it in 2010 and 2018. Moreover, Nigeria's HDI lies below Medium Human Development and the World Average throughout the 2005-2018 period. The gap between Nigeria's HDI and World Average is quite significant and persistent.

TABLE 2(a)

Undp Human Development Index (Hdi) Trend

\begin{tabular}{|l|c|c|c|}
\hline \multicolumn{1}{|c|}{ COUNTRY/CATEGORY } & $\mathbf{2 0 0 5}$ & $\mathbf{2 0 1 0}$ & $\mathbf{2 0 1 8}$ \\
\hline NIGERIA* & 0.466 & 0.484 & 0.534 \\
\hline Sub-Sahara African Average & 0.452 & 0.498 & 0.541 \\
\hline Medium Human Development & 0.565 & 0.642 & 0.686 \\
\hline World Average Human Development Index & 0.667 & 0.697 & 0.731 \\
\hline Nigeria-Medium Human Development Gap & 0.099 & 0.158 & 0.152 \\
\hline NIGERIA-World Average Development Gap & 0.201 & 0.213 & 0.197 \\
\hline
\end{tabular}

Source: UNDP Human Development Reports (2010, 2019)

$*$ HDI figure for Nigeria is not available for earlier periods.

TABLE 2 (b)

2018 HDI Rank among Large Developing Countries of Medium and Low Human Development Categories

\begin{tabular}{|r|l|c|c|c|c|}
\hline S/N & COUNTRY & $\begin{array}{c}\text { HDI } \\
\text { Rank }\end{array}$ & $\begin{array}{c}\mathbf{2 0 1 8} \\
\text { HDI }\end{array}$ & $\begin{array}{c}2010 \\
\text { HDI }\end{array}$ & $\begin{array}{c}2005 \\
\text { HDI }\end{array}$ \\
\hline 1 & MEXICO & $\mathbf{7 6}$ & 0.767 & 0.743 & 0.724 \\
\hline 2 & THAILAND & $\mathbf{7 7}$ & 0.765 & 0.724 & 0.685 \\
\hline 3 & BRAZIL & $\mathbf{7 9}$ & 0.761 & 0.727 & 0.705 \\
\hline 4 & COLOMBIA & $\mathbf{7 9}$ & 0.761 & 0.719 & 0.680 \\
\hline 5 & CHINA & $\mathbf{8 5}$ & 0.758 & 0.706 & 0.645 \\
\hline 6 & PHILIPPINES & $\mathbf{1 0 6}$ & 0.712 & 0.665 & 0.638 \\
\hline 7 & INDONESIA & $\mathbf{1 1 1}$ & 0.707 & 0.661 & 0.640 \\
\hline 8 & SOUTH AFRICA & $\mathbf{1 1 3}$ & 0.705 & 0.649 & 0.608 \\
\hline 9 & EGYPT & $\mathbf{1 1 6}$ & 0.700 & 0.665 & 0.645 \\
\hline 10 & VIET NAM & $\mathbf{1 1 8}$ & 0.693 & 0.654 & 0.598 \\
\hline 11 & INDIA & $\mathbf{1 2 9}$ & 0.647 & 0.581 & 0.527 \\
\hline 12 & BANGLADESH & $\mathbf{1 3 5}$ & 0.614 & 0.545 & 0.494 \\
\hline 13 & MYANMAR & $\mathbf{1 4 5}$ & 0.584 & 0.530 & 0.472 \\
\hline 14 & KENYA & $\mathbf{1 4 7}$ & 0.579 & 0.543 & 0.479 \\
\hline 15 & PAKISTAN & $\mathbf{1 5 2}$ & 0.560 & 0.526 & 0.504 \\
\hline 16 & NIGERIA & $\mathbf{1 5 8}$ & 0.534 & 0.484 & 0.466 \\
\hline 17 & TANZANIA & $\mathbf{1 5 9}$ & 0.528 & 0.493 & 0.419 \\
\hline 18 & ETHIOPIA & $\mathbf{1 7 3}$ & 0.470 & 0.412 & 0.339 \\
\hline 19 & CONGO (Democratic Rep. of the) & $\mathbf{1 7 9}$ & 0.459 & 0.407 & 0.292 \\
\hline
\end{tabular}

Source: United Nations Human Development Reports/Statistical Annex (2018, 2019).

Table 2(b) presents the Human Development Index million and above. The countries that ranked below Nigeria were (HDI) for 2005, 2010, 2018 and the global ranks in 2018 for Ethiopia and the Democratic Republic of the Congo, which was nineteen significantly large developing countries comparable to going through extremely severe political instability and Nigeria. The countries selected are those with a population of 50 insurgency. 


\title{
International Journal of Business and Social Science Research
}

\author{
Vol: 3, Issue: 2 \\ February/2022 \\ DOI: http://dx.doi.org/10.47742/ijbssr.v3n2p1 \\ https://ijbssrnet.com/index.php/ijbssr
}

\subsection{Assessment by Poverty Index, Child Mortality Rate and Maternal Mortality Ratio}

Table 3 shows the poverty index, child mortality rate, and maternal mortality ratio for the selected nineteen large developing countries. As for the poverty index, Nigeria with a poverty index of 53\% is the second worst after the Democratic Republic of Congo with $76.6 \%$. Countries comparable to Nigeria in terms of population, resources, and socioeconomic stability, such as Bangladesh, Indonesia, and Pakistan, have respectively $14.8 \%$, $5.7 \%$, and $3.9 \%$ poverty index, a far cry from Nigeria's $53.5 \%$.

\section{TABLE 3}

The situation is also woeful for Nigeria when it comes to the child mortality rate and maternal mortality ratio. Table 3 reveals Nigeria as the worst among the large developing countries. While the mortality rate for Nigeria is a triple-digit of 119.9 per thousand, all other countries have double-digit rates. As for the critical indicator of maternal mortality ratio, Nigeria is also by far the worst with a figure of 917 per 100,000. Democratic Republic of Congo, Tanzania, Ethiopia, Kenya, and South Africa have much less maternal mortality ratios of $378,524,401,342$, and 119 respectively.

Poverty Index, Child Mortality Rate and Maternal Mortality Ratio (Among developing countries with over 50 million population)

\begin{tabular}{|c|c|c|c|c|c|}
\hline $\mathrm{S} / \mathrm{N}$ & $\begin{array}{l}2018 \\
\text { HDI } \\
\text { Rank }\end{array}$ & $\begin{array}{c}\text { COUNTRY/ } \\
\text { REGION }\end{array}$ & $\begin{array}{l}\text { Poverty Index } \\
\text { (Pop \% living } \\
\text { below } \$ 1.90 \text { ) }\end{array}$ & $\begin{array}{c}\text { Child } \\
\text { Mortality } \\
\text { Rate } 2018\end{array}$ & $\begin{array}{c}\text { Maternal } \\
\text { Mortality } \\
\text { Ratio } 2017\end{array}$ \\
\hline 1 & 76 & MEXICO & 2.5 & 12.7 & 33 \\
\hline 2 & 77 & THAILAND & 0.0 & 9.1 & 37 \\
\hline 3 & 79 & BRAZIL & 4.8 & 14.4 & 60 \\
\hline 4 & 79 & COLOMBIA & 3.9 & 14.2 & 83 \\
\hline 5 & 85 & CHINA & 5.4 & 8.6 & 29 \\
\hline 6 & 106 & PHILIPPINES & 7.8 & 28.4 & 121 \\
\hline 7 & 111 & INDONESIA & 5.7 & 25.0 & 177 \\
\hline 8 & 113 & SOUTH AFRICA & 18.9 & 33.8 & 119 \\
\hline 9 & 116 & EGYPT & 1.3 & 21.2 & 37 \\
\hline 10 & 118 & VIET NAM & 2.0 & 20.7 & 43 \\
\hline 11 & 129 & INDIA & 21.2 & 36.6 & 145 \\
\hline 12 & 135 & BANGLADESH & 14.8 & 30.2 & 173 \\
\hline 13 & 145 & MYANMAR & 6.2 & 46.2 & 250 \\
\hline 14 & 147 & KENYA & 36.8 & 41.1 & 342 \\
\hline 15 & 152 & PAKISTAN & 3.9 & 69.3 & 140 \\
\hline 16 & 158 & NIGERIA & 53.5 & 119.9 & 917 \\
\hline 17 & 159 & TANZANIA & 49.1 & 53.0 & 524 \\
\hline 18 & 173 & ETHIOPIA & 27.3 & 55.2 & 401 \\
\hline 19 & 179 & CONGO (DRC) & 76.6 & 88.1 & 378 \\
\hline
\end{tabular}

World Bank 2019 (World Dev Indicators Database); W.H.O.; Wikipedia.org.

2.3 Assessment by Food Security, Long-term Survival, ratio of total export earnings fluctuated between $92 \%$ and $98 \%$ and Self-Reliance

We have available statistics for food exports and imports, oil exports. The ratio of non-oil exports to non-oil imports is as well as non-oil exports and imports for Nigeria. The ratio of presented in Table 4 for the period 2012 to 2017. The Table shows food exports to food imports serves as a measure of self-reliance, that the ratio of food export to import throughout the 2012-2016 and food security for long-term survival. These are presented in period has been below $0.1 \%$, which is alarming. The Table also Table 4 for 2012-2016 available data. Similarly, the non-oil shows that the ratio of non-oil exports to non-oil imports has also exports, which comprise agricultural produce and manufactured been very small, fluctuating between $7 \%$ and $16 \%$ during the products reflect the nation's self-reliance when compared with 2012-2017 period, indicating an overwhelming dependence on oil counterpart non-oil imports. Export earnings from crude oil as a export earnings.

TABLE 4

Food Export/Import Ratio, Non-oil Export/Import Ratio

\begin{tabular}{|l|r|r|r|r|r|c|}
\hline \multicolumn{1}{|c|}{ Values \& Indicators } & \multicolumn{1}{c|}{2012} & \multicolumn{1}{c|}{2013} & \multicolumn{1}{c|}{2014} & \multicolumn{1}{c|}{2015} & \multicolumn{1}{c|}{2016} & 2017 \\
\hline Food Exports (N'billion) & 1.18 & 1.37 & 1.57 & 1.80 & 2.06 & - \\
\hline Food Imports (N'billion) & $1,464.9$ & $1,712.1$ & $1,841.7$ & $1,927.4$ & $1,973.3$ & - \\
\hline Non-oil Exports (N'billion) & 879.3 & $1,130.2$ & 953.5 & 660.7 & 656.7 & $1,074.9$ \\
\hline Non-oil Imports (N'billion) & $6,702.3$ & $7,010.0$ & $8,323.7$ & $9,350.8$ & $7,096.0$ & $8,189.4$ \\
\hline Food Export/Import ratio \% & $\mathbf{0 . 0 8}$ & $\mathbf{0 . 0 8}$ & $\mathbf{0 . 0 9}$ & $\mathbf{0 . 0 9}$ & $\mathbf{0 . 1 0}$ & - \\
\hline Non-oil Export/Import ratio \% & $\mathbf{1 3 . 1 2}$ & $\mathbf{1 6 . 1 2}$ & $\mathbf{1 1 . 4 6}$ & $\mathbf{7 . 0 7}$ & $\mathbf{9 . 2 6}$ & $\mathbf{1 3 . 1 3}$ \\
\hline
\end{tabular}

2.4 Assessment by Indicators of Environmental Pollution and Degradation
The major environmental problem in Nigeria is the dreadful rate of deforestation in most of the Northern region of the country. 


\author{
Vol: 3, Issue: 2 \\ February/2022 \\ DOI: http://dx.doi.org/10.47742/ijbssr.v3n2p1 \\ https://ijbssrnet.com/index.php/ijbssr
}

Atmospheric pollution is, however, insignificant nationally incapable of breaking the shackle of underdevelopment and has except for the oil-producing areas of the Niger Delta. (data.worldbank.org, 2019).

However, for the dreadful environmental problem of deforestation in Nigeria, the United Nations Food and Agricultural Organisation (FAO) reported that Nigeria had the highest deforestation in the world in 2005 , and has lost $55.7 \%$ of primary forest from 2000 to 2005 , claiming furthermore that only half of the forests that existed in 2007 remained ten years after (www.fao.org). According to the FAO forest resources assessment (fra-data.fao.org), the rate of deforestation in Nigeria from 1990 to 2020 is 163,000 hectares per year, while forest expansion was a mere 100 hectares per year from 1990 to 2000, and zero from 2000 to 2020. Another study estimated that the desertification rate reached $63.8 \%$ in 2015 , that is, $580,841 \mathrm{~km} 2$ has been lost to desertification out of $909,890 \mathrm{~km} 2$ land space (Olagunju, 2015). Desertification is a much more serious challenge for the environmental sustainability of national development.

The major causes of deforestation are the widespread and dominant use of wood as fuel in rural areas, subsistence farming, logging, timber export, and bush burning. The deforestation and desertification affect mostly 15 northern States, which have become severely impoverished, causing continual waves of migration especially of Nomadic herdsmen towards the middlebelt and south, resulting in recurrent ethnic and regional conflicts between herdsmen and crop farmers.

All the indicators of growth and structural transformation and social development show that Nigeria has been afflicted with perpetual underdevelopment, lagging behind all the comparable and contemporary developing countries. The country appears

not been able to make any progress towards sustained economic and social development, despite its enormous human and material resources.

\section{THE STRUCTURAL THEORY OF DEVELOPMENT POLICY AND OBSTACLES TO EFFECTIVE DEVELOPMENT POLICIES}

The Structural Theory of Development Policy postulates that a development objective function can be fairly precisely formulated by policymakers articulating the yearnings and enlightened aspirations of the generality of the people. Furthermore, the theory postulates that for any economic system, there exist four types of inter-related variables, namely:

(i) Policy Instruments or Controlled Variables (vector $\boldsymbol{x}$ ), such as tax rates, subsidies, budget deficit, and capital expenditure, exogenous to the economic system.

(ii) External exogenous variables or Non-Controlled Variables (vector $\boldsymbol{u}$ ) that are determined entirely outside the economic system and government control, such as prices of crude oil and other primary commodities, as well as rainfall and temperature.

(iii) Target Endogenous Variables of the economic system (vector $\boldsymbol{y}$ ), such as per capita income, poverty index, employment rate, inflation rate, and food security index, which are the ultimate objectives of the development policy, incorporated in Development Objectives Function $[\boldsymbol{w}(\boldsymbol{y})]$.

(iv) Non-target endogenous variables of the economic system (vector $z$ ), such as savings and investment expenditure, which interact with the target endogenous variables.

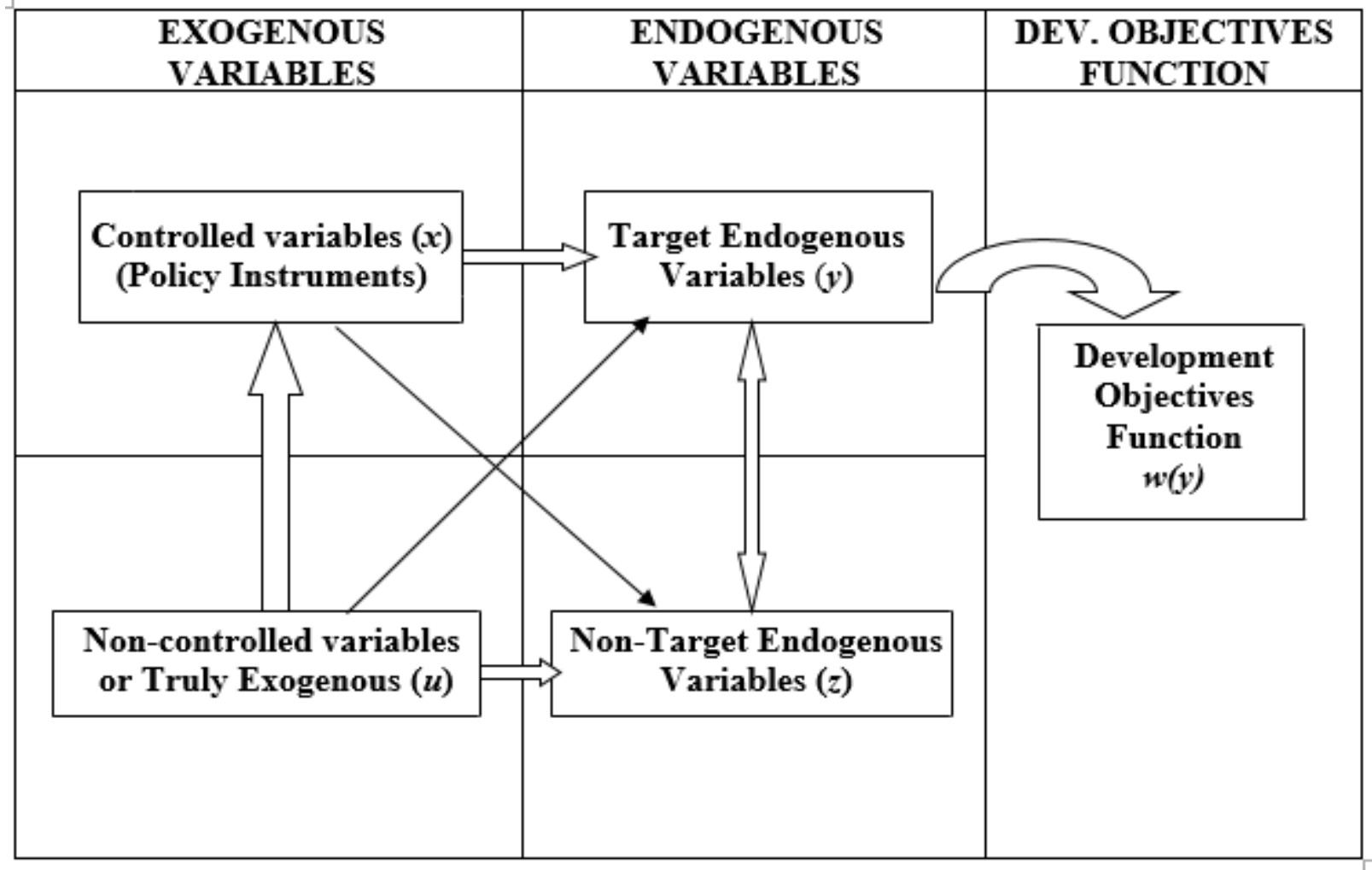

Fig. 1: The Structural Theory of Development Policy

Source: Adapted from Tinbergen's “Theory of Economic Policy” (Tinbergen, 1978). 


\author{
Vol: 3, Issue: 2 \\ February/2022 \\ DOI: http://dx.doi.org/10.47742/ijbssr.v3n2p1 \\ https://ijbssrnet.com/index.php/ijbssr
}

The Structural Theory is illustrated in Fig.1 Flowchart. Given this theory, it is imperative to understand the precise interactions among the variables. So, development policy has to be preceded by the task of economic modeling to establish empirically the nature of relationships among the variables. With enlightened economic-system modeling, objective articulation of appropriate development policies, and effective implementation of the policies, the economic system will tend towards producing consistent and desirable outcomes, which will have a positive impact on the national development objectives.

If, however, the political-economic affairs are left to government ineptitude, applying fallacious theories (false paradigms), or pursuing conflicting parochial, partisan, and perverse group interests, the system will produce distorted, divergent and unstable series of outcomes, leaving the nation to drift without any sustainable development goal. To fully appreciate the theory, the various segments of the structural theory constituting the obstacles to effective development policies and consequent perpetual underdevelopment are highlighted.

The segments of the theory from where obstacles to the effectiveness of development policies could emanate may be categorized into the following four areas:

(i) Wrong Articulation of National Development Objectives: Correct articulation of national development objectives requires a political process that compels policymakers towards articulating and integrating the yearnings and enlightened aspirations of the people equitably. Such a political process may be achieved sustainably through functional democratic institutions. Otherwise, government authorities may pursue conflicting objectives under the influence of powerful interest groups, including the political class, ethnoreligious groups, corporate bodies, professional associations, powerful trade unions, and external socioeconomic interests.

(ii) Deficient knowledge of the structure and dynamics of the economic system: Unless the economic system and its interactions with policy instruments and exogenous variables are fairly well understood, development policies may be wrongly formulated and hence fail to achieve desired goals. This underscores the importance of studying the system and applying relevant development theories, which have been subjected to empirical validation, rather than adopting plausible false paradigms.

(iii) External dependence and vulnerability of the economy: Where the economy is excessively dependent on, or vulnerable to, external exogenous factors, quantitative development policies will be inadequate for the achievement of sustainable development. So, there will be the need for more fundamental policies to restructure the economic system to minimize its dependence on external exogenous factors.

(iv) Government capacity to execute policy instruments and deliberate abuse of power: It is often assumed that government possesses adequate capacity to execute its policies. Civil servants and government agencies responsible for the implementation and monitoring of execution of development policies and projects may not properly perform on account of ineptitude, embezzlement, misappropriation, and divided loyalty.

\subsection{Towards the Resolution of the Obstacles to Effective Development Policies}

We first discuss the approaches towards resolving the three socio-political obstacles (i), (iii), and (iv) outlined above. But it is regarding obstacle (ii), concerning inadequate knowledge of the structure and dynamics of the economic system, that the paper in Section 3.2 deals with specially and extensively, being the area of empirical economic analysis.

About obstacle (i) on the correct articulation of development goals by the policymakers, it is only an appropriate political process that can lead to a truly people-oriented articulation of development objectives. However, the political party system with godfatherism and financiers' entrenched interests and their corrupt and questionable sources of wealth will make the elimination of corruption and bad governance a Herculean task.

As for obstacle (iii) on the extent of the economic-system dependence on external exogenous variables, fundamental policies have to be designed to reduce the dependence and vulnerability of the economic system to the external world and natural forces. Such fundamental policies can be classified into structural and reformative policies, which go beyond the superficial quantitative policies. Tinbergen $(1960,1978)$ introduced these distinctions in the levels of development policies. At the quantitative level of policy, we concentrate on the manipulation of the magnitudes of policy instruments to bring about quantitative and possibly qualitative changes in target variables. Where a quantitative policy cannot achieve the development objectives adequately, we explore structural policy, and where that fails, we explore reformative policy. The reformative policy is the most fundamental restructuring of the economic system, possessing the greatest socioeconomic potential in achieving sustainable development.

In respect of obstacle (iv) concerning proper execution of development policies, this could be mitigated through effective legislature's oversight function, and the roles of an independent judiciary and free press to expose and sanction corrupt practices. 3.2 Illustrating Deficient Knowledge of Economic System with a major False Paradigm

Critical development policies adopted in less-developed countries are often based on theories that do not apply to their particular circumstances but which the policymakers embrace without expert empirical analysis of their relevance to the economy. The appropriate development policy produces expected results within a pre-determined period.

A major and critical example of such an inapplicable theory is the classical excess demand theory of the foreign exchange market based on the assumption of a downward sloping demand curve and an upward-sloping supply curve for foreign exchange. In other words, excess demand for foreign exchange 


\title{
International Journal of Business and Social Science Research
}

\author{
Vol: 3, Issue: 2 \\ February/2022 \\ DOI: http://dx.doi.org/10.47742/ijbssr.v3n2p1 \\ https://ijbssrnet.com/index.php/ijbssr
}

can be addressed by currency devaluation or by raising the exchange rate towards the equilibrium rate. As a result of currency devaluation, the consequent rise in the domestic prices of imported goods is expected to cause foreign exchange demand for imports to fall, while the consequent rise in the domestic prices of export products is expected to serve as an incentive for exporters to increase the supply of export products and the supply of foreign exchange earnings. The decrease in the demand for foreign exchange and the increase in the supply of foreign exchange is expected to reduce or eliminate the excess demand and thus promote the balance of payment equilibrium or eliminate the balance-of-payments deficit. The theory is valid for developed countries that export largely manufactured products for which global demand is price and income elastic. It may not apply to developing countries like Nigeria that export largely primary commodities having price and income inelastic global demand and whose imports are price inelastic and income elastic. The nonapplicability of the theory is further worsened by two factors: first is the rapid (double-digit) inflation rate that erodes competitive advantage in respect of a demand for domestic products and also promotes preference for stable foreign currencies for holding household and corporate savings; second is the severe political instability and unbridled corruption that fuels calamitous capital flight. These factors establish the possibility that excess demand for foreign exchange is a function of other variables that may be more significant and run counter to the exchange rate. So, as we shall presently demonstrate, the hypothesis that exchange rate is the major determinant of excess demand for foreign exchange is invalid and hence a false paradigm for countries characterized by those political-economic factors.

As expected, the balance of payments (BOP) did not improve during the 1986-2019 period of the IMF Structural Adjustment Programme (SAP) in Nigeria, when the foreign exchange market was deregulated and the domestic currency depreciated considerably as Naira exchange rate to US Dollar (N/\$) rose from 0.89 in 1985 to 306.95 in 2019 . Fig. 2 shows the graphical relationship of BOP and Exchange Rate (EXR) during the period. The regression of BOP on EXR gave a regression coefficient of 0.0175 , which is not all significant ( $t$ statistic $0.731 ; R 20.0142 ; D-W$ statistic 0.963$)$. On account of the insignificant $R 2$ and serious autocorrelation as reflected in low $D$-W statistic, we included lagged BOP as an explanatory variable, resulting in a better $R 2$ of 0.246 and $a D$-W statistic of 2.042. The lagged BOP turns out to be quite significant (3.317 $t$ statistic) but the regression coefficient of exchange rate falls considerably to 0.0007 (0.0338 t-statistic). The details of regression equations are presented in Appendix III.

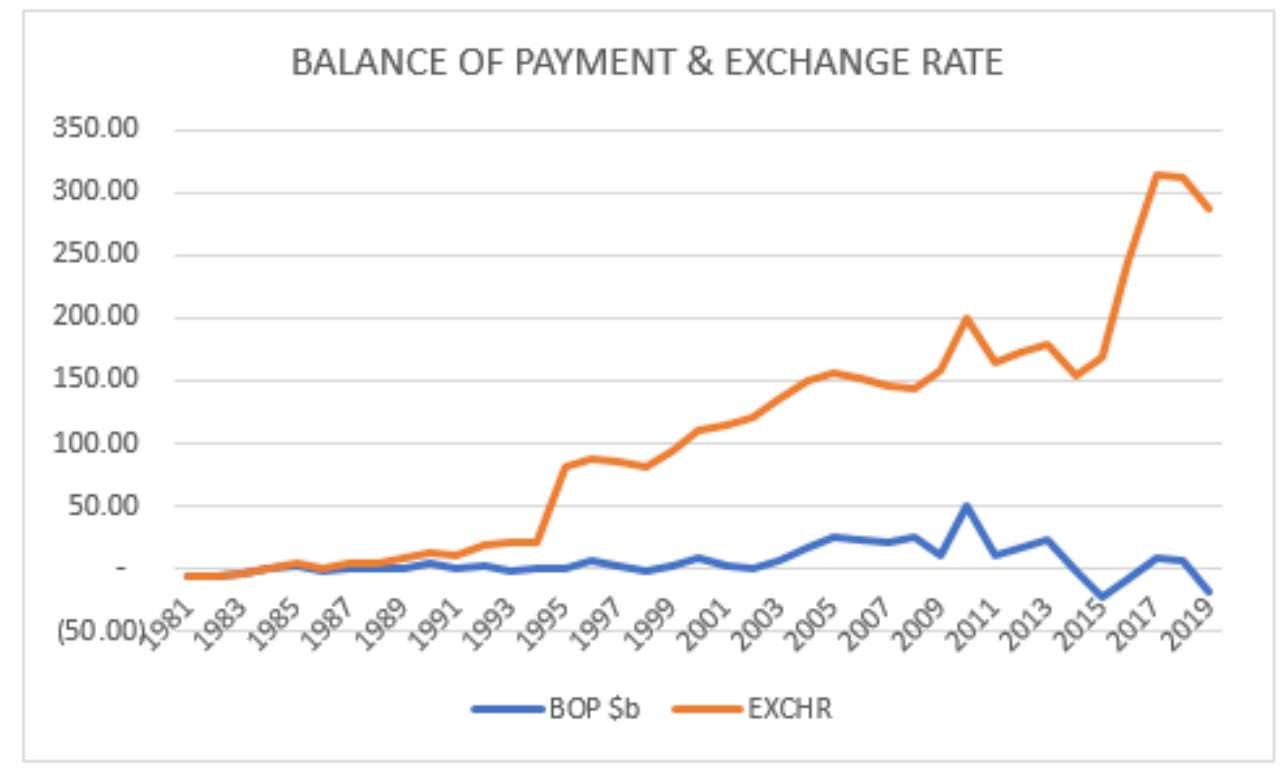

Fig. 2: BOP and Naira Exchange Rate Graphs 1981-2019 based on Statistical Tables of Appendix II.

As for the deregulation policy's impact on imports, the rational for the people to hide stolen wealth and to transfer rising foreign exchange rate could not deter importation (and legitimate and illegitimate incomes abroad in stable foreign foreign-exchange demand). This is understandably due to the currencies.

highly inelastic import demand for plant and machinery, intermediate industrial inputs, and payments for factor services, especially foreign-debt servicing and repatriation of factor incomes abroad. Moreover, the demand for foreign exchange for capital flight is enormous in the environment of severe political instability, rapid inflation rate, and unbridled corruption. ${ }^{2}$ It is

The output and export of manufactured goods (foreign exchange supply component) did not respond positively to foreign exchange market deregulation as expected. As illustrated in Fig.3, manufacturing output in US\$ declined secularly with rising Naira/ $\$$ exchange rate as opposed to the expectation of excess demand theory for foreign exchange that currency devaluation 


\title{
International Journal of Business and Social Science Research
}

\author{
Vol: 3, Issue: 2 \\ February/2022 \\ DOI: http://dx.doi.org/10.47742/ijbssr.v3n2p1 \\ https://ijbssrnet.com/index.php/ijbssr
}

will promote output and exports of manufactured goods. This currency depreciation on domestic prices of export commodities. might be explained by the sector's excessive dependence on The situation is worsened by terrible domestic insecurity, political imported plant and machinery, technology, and intermediate instability, and the severely inadequate energy and transportation inputs which would cost much more with currency depreciation infrastructures and their prohibitive costs, thus constituting an and raise production cost, offsetting the positive impact of unfavorable investment environment.

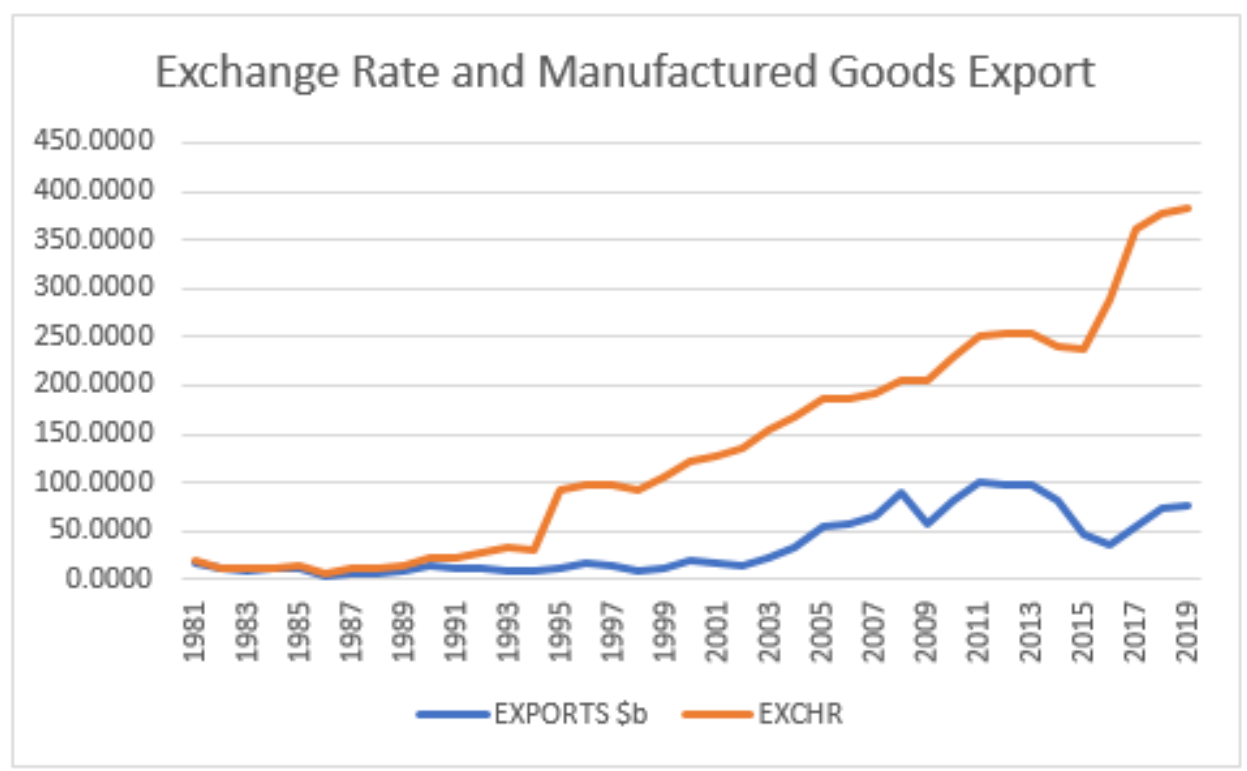

Fig. 3: Manufacture Goods Export and Exchanger Rate 1981-2019 based on Statistical Tables of Appendix III.

\subsection{Econometric Analysis}

These observations were explored econometrically, with five model formulations presented and discussed in Appendix I. The detailed regression equations are presented in Appendix III. The dependent variable is Foreign Exchange Excess Demand (FXD), that is, current account Balance of Payments Deficit while the main explanatory variable is Exchange Rate N/\$ (EXR). Briefly, the various model formulations are:

Simple Equation model, given by:

$\mathrm{FXD}_{\mathrm{t}}=\beta_{0}+\beta_{1} \mathrm{EXR}_{\mathrm{t}}+\mu_{\mathrm{t}} ; E\left(\mu_{\mathrm{t}}\right)=0 ; \beta_{0}>0, \beta_{1}<$ 0 are a-priori expectations.

Lag distributed model where the dependent variable (FXD) is a function of current and lagged values of the explanatory variable $\left(\mathrm{EXR}_{\mathrm{t}}\right.$ i, $\mathrm{i}=1,2,3, \ldots, \mathrm{k}$ ) such that through Koyck lag transformation the dependent variable reduces to a function of current explanatory variable and lagged dependent variable, given by:

$\mathrm{FXD}_{\mathrm{t}}=\beta_{0}+\beta_{1} \mathrm{EXR}_{\mathrm{t}}+\beta_{2} \mathrm{FXD}_{\mathrm{t}-1}+\mu_{\mathrm{t}} ; E\left(\mu_{t}\right)=0$ $\beta_{0}>0, \beta_{1}<0$ and $0<\beta_{2}<1$, are a-priori expectations of excess demand theory.

(iii) Partial adjustment model, where the dependent variable FXD is made to adjust to unobservable desired value $\mathrm{FXD}^{*}$ that depends precisely on current explanatory variable EXR, by an adjustment coefficient $(0<\lambda<1)$. The result is given by:

$\mathrm{FXD}_{\mathrm{t}}=\beta_{0}+\beta_{1} \mathrm{EXR}_{\mathrm{t}}+\beta_{2} \mathrm{FXD}_{\mathrm{t}-1}+\mu_{\mathrm{t}} ; E\left(\mu_{t}\right)=0$

$\beta_{0}>0, \beta_{1}<0.0<\beta_{2}<-\beta_{1}$ as a-priori expectations. (iv)

Adaptive expectation as applicable to a market model where the current price (Exchange Rate) is estimated in the previous period based on the gap by which the actual price differs from the expected in the previous period, through an adaptation coefficient that reviews the estimate upwards for a positive gap and downwards for a negative gap. The resultant regression equation is given by:

$\mathrm{FXD}_{\mathrm{t}}=\beta_{0}+\beta_{1} \mathrm{EXR}_{\mathrm{t}-1}+\beta_{2} \mathrm{FXD}_{\mathrm{t}-1}+\mu_{\mathrm{t}} ; E\left(\mu_{t}\right)=0$. $\beta_{0}>0, \beta_{1}<0$, and $\beta_{2}>0$, as a-priori expectations.

(v) Dynamic (Cob-web) market model where the demand (for foreign exchange) is a negative function of current price (exchange rate) and positive function of current national income, while the supply (for foreign exchange) is a positive function of price, lagged one period. The resultant regression equation is given by:

$\mathrm{FXD}_{\mathrm{t}}=\beta_{0}+\beta_{1} \mathrm{EXR}_{\mathrm{t}}+\beta_{2} \mathrm{EXR}_{\mathrm{t}-1}+\beta_{3} \mathrm{Y}_{\mathrm{t}}+\mu_{\mathrm{t}} ; E\left(\mu_{\mathrm{t}}\right)$ $=0$.

$\beta_{0}>0, \beta_{1}<0, \beta_{2}<0,-1<\beta_{3}<1$ as a-priori expectations.

As noted in Appendix I, model formulations (ii) and (iii) result in the same specification. Model specification (i) also results in the same specification when the lagged dependent variable is introduced to address auto-correlation as reflected by extremely low D-W statistic.

3.2.2 Summary Results of the regression equations and Interpretations.

The model specifications (i), (ii), and (iii) above result in the same regression: 


\title{
International Journal of Business and Social Science Research
}

\author{
Vol: 3, Issue: 2 \\ February/2022 \\ DOI: http://dx.doi.org/10.47742/ijbssr.v3n2p1 \\ https://ijbssrnet.com/index.php/ijbssr
}

$F X D_{t}=-2.5025-0.0337\left(E X R_{t}\right)+0.515\left(F X D_{t-1}\right)$

t-statistic (-0.841) (-0.337) (3.317) $\mathrm{R}^{2}=0.2462$.

So, for all the three model specifications (i), (ii), and (iii), the regression coefficient of the exchange rate is not significantly different from zero, whether we use nominal exchange rate (EXR) or real exchange rate (REXR), and so the hypothesis of excess demand theory is rejected.

The regression equation for the adaptive expectation model specification (iv) is given as:

$F X D_{t}=-2.2494-0.0039\left(E X R_{t-1}\right)+0.5091\left(F X D_{t-1}\right)$

t-statistic (-0.7722) (-0.1615) (3.2147) $\mathrm{R}^{2}=0.2467$.

Again, the hypothesis of foreign exchange excess demand theory is rejected as the regression coefficient of the exchange rate is not significantly different from zero, as opposed to the prior expectation of a significantly negative regression coefficient.

Finally, the regression of the cobweb model specification (v) is given as:

(a) $F X D_{t}=-4.4154+0.2554\left(E X R_{t}\right)-0.2927\left(E X R_{t-1}\right)+$ $0.0009(G D P)$

t-statistic: $(-1.2595)$
$\begin{aligned} & (0.0522) \\ & \mathrm{R}^{2}=0.1234 ; \quad \operatorname{adj}\left(\mathrm{R}^{2}\right)=0.0461 ;\end{aligned} \quad \mathrm{D}-\mathrm{W}=1.0141$.

(b) $F X D_{t}=-3.5512+0.0947\left(E X R_{t}\right)-0.1194\left(E X R_{t-1}\right)+$ $0.0109(G D P)+0.4749\left(F X D_{t-1}\right)$

$\begin{array}{cc}\text { t-statistic: }(-1.0866) \quad(0.6957) \\ (0.06457) & (2.5575) \\ \mathrm{R}^{2}=0.2684 ; \quad \operatorname{adj}\left(\mathrm{R}^{2}\right) & =0.1797 ;\end{array}$

$(-0.8092)$

$\mathrm{D}-\mathrm{W}=1.9414$

The lagged dependent variable $F X D_{t-1}$ is introduced in regression (b) to address the significant serial correlation as reflected in the low $D$-W statistic and the extremely low $R^{2}$ in regression (a). Besides, the regression coefficients of $E X R_{t}$ and $E X R_{t-1}$ are both expected to be negative, but they assume opposite signs, and the regression coefficients of EXR in $(b)$ are not significant.

In all the regressions of the model specifications, the hypothesis of inverse relationship between excess demand for foreign exchange (FXD) and Exchange Rate (EXR) is rejected. We have argued that foreign exchange excess demand for a country like Nigeria is more related to the problems of the rapid inflation rate, immense capital flight connected with corruption and political instability, inelastic demand for imported goods, predominant primary-commodity exports, and unavoidable payments for non-factor and factor services (especially debt servicing).

We, therefore, explore the impact of the exchange rate on some components of foreign exchange excess demand. The components are imports of goods and Net Services (MNS), expected to be negatively dependent on the exchange rate and positively on GDP and manufacturing sector output (MFQ) expected to respond positively to the exchange rate.
As for the imports (MNS), the results below showed that foreign exchange demand for imports did not respond negatively to nominal or real exchange rate $(R E X R)$ as expected:

$$
M N S=-23.859+0.0638(R E X R)+0.1860(G D P)
$$

t-statistic: $-3.6343 .63413 .910 R^{2}=0.8817 D-W=1.5799$

The fact that the exchange rate has promoted demand for foreign exchange rather than discouraged it is quite understandable from the political economy of Nigeria. In a situation of inelastic demand for imports of goods and services, immense capital flight fuelled by unbridled corruption of political office holders, and severe political instability, the rising exchange rate will not discourage demand for foreign exchange. Furthermore, the rising exchange rate results in a rapid inflation rate, making it rational to keep household and corporate savings abroad in stable foreign currencies.

In the regression of manufacturing sector output $(M F Q)$, we found as shown below that exchange rate did not promote manufacturing sector output as expected:

$$
M F Q=-0.4514+0.0047\left(E X R_{t}\right)+0.7994\left(M F Q_{t-1}\right)
$$

$t$-statistic-0.1172 $0.182315 .0097 R^{2}=0.8965 D-W=2.5237$

So, the argument that deregulation of the foreign exchange market will promote exports of manufactured goods is not validated by empirical evidence in Nigeria. The reasons for this failure include the heavy dependence of the manufacturing industries on imported plant and machinery and intermediate inputs, whose costs escalate with the rising exchange rate, eroding the profit margins of the manufacturing industries. Worse still, the industries face an extremely unfavorable investment environment of severely inadequate and high costs of energy and transportation infrastructure and terrible insecurity. This has adversely affected the competitiveness of the sector resulting in secularly declining outputs from 2,544.14 billion USD in 1985 to 54.67 billion USD in 2019 , in spite of the fact that exchange $\mathrm{N} / \$$ kept rising substantially from 1985 to 2019.

In conclusion, as long as the country exports mainly primary commodities and is characterized by inelastic import demand, excessive corruption, rapid inflation rate, dreadful insecurity, and political instability, acutely inadequate energy and transportation infrastructure, deregulation of the foreign exchange market will be counterproductive as it will worsen the inflationary situation and economic instability, creating a vicious circle, without achieving the objective of promoting a balance of payment equilibrium. Under such circumstances, it is advisable to regulate the foreign exchange market to promote the importation of non-competitive goods and services required for social and physical infrastructure and industrial development. Such a policy demands substantial accountability and integrity, which is indispensable for good governance and sustainable development.

\section{SUMMARY AND CONCLUSION}

Substantial evidence was marshaled to establish that subSaharan African countries (excepting South Africa) have remained perpetually underdeveloped for several decades and the development gap between them and developed countries had been widening. 


\author{
Vol: 3, Issue: 2 \\ February/2022 \\ DOI: http://dx.doi.org/10.47742/ijbssr.v3n2p1 \\ https://ijbssrnet.com/index.php/ijbssr
}

For a critical analysis of underdevelopment in Nigeria, as

a case study, the paper proposed a pragmatic approach to sustainable development through the following components:

(i) Economic growth and structural transformation;

(ii) Rapid population growth relative to land resources and economic growth;

(iii) Widening income inequality;

(iv) Extent of economic, technological, and political dependence of the country;

(v) Imbalance in inter-sector development and extent of single-sector domination;

(vi) Rapidity of inflation rate;

(vii) Environmental pollution and degradation;

(viii) Intellectual, moral, and social degeneration.

Based on indicators of economic growth and structural transformation, and development indicators of Human Development Index (HDI), Child Mortality Rate, Maternal Mortality Ratio, Poverty index, and Food Export-Import Ratio (or

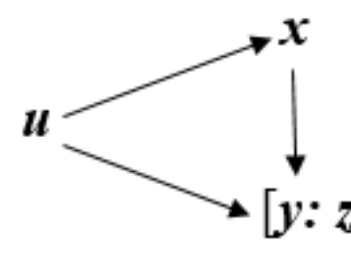

food security index), Nigeria has remained at the bottom of global underdevelopment. In respect of the environmental sustainability index, the country's situation has been worsening, particularly with deforestation.

Having demonstrated that Nigeria has remained perpetually underdeveloped for over six decades, lagging behind contemporary developing countries, the paper deduces the root causes of the perpetual underdevelopment, by means of a Structural Theory of Development Policy.

For any economic system, the structural theory of development policy postulates an interrelationship among four categories of economic system variables comprising policy instruments (vector $\boldsymbol{x}$ ), the external exogenous variables (vector $\boldsymbol{u}$ ), target and non-target endogenous variables (vectors $y$ and $z$ ), affecting development objective function $[\boldsymbol{w}(\boldsymbol{y})]$.

The model of the interrelationship of the variables is summarily given as:
The model implies that vector $\boldsymbol{u}$ of external and exogenous factors has impacts on policy instruments $(\boldsymbol{x})$ and vectors of endogenous variables $[y: z]$, while the target variables $(y)$ are the arguments of the development objective function $w(y)$.

Given this theory, the following constitute the obstacles that explain the failure of development policies, hence perpetual underdevelopment:

(i) Inappropriate or self-interest articulation of national development objectives;

(ii) Deficient knowledge of the economic system and adoption of inappropriate development theories, considering the peculiarities of the economy;

(iii) Excessive vulnerability of the economic system to external exogenous factors, demanding reformative policies to reduce economic-system vulnerability;

(iv) Inadequate policy implementation capacity due to ineptitude, self-interest, corruption, and disloyalty of agencies responsible for the implementation of policy instruments.

The paper discussed the ways out, which were considered hardly surmountable. For item (i) on the articulation of development goals, an appropriate political process was considered the way out for a genuine people-oriented articulation of development objectives. However, the political party system with godfatherism and financiers' entrenched interests and their corrupt and questionable sources of wealth makes the elimination of corruption and bad governance a Herculean task. As for item (iii) on the extent of the economic-system dependence on external exogenous variables, fundamental policies have to be designed to reduce the dependence and vulnerability of the economic system to the external world and natural forces. The obstacle concerning item (iv) on the inadequate capacity for execution of development policies could be mitigated through effective legislature's oversight function, and the roles of an independent judiciary and free press to sanction and expose corrupt practices.

The paper considered item (ii) the deficient knowledge of the economic system the most crucial factor for empirical economic analysis. This is illustrated with foreign-exchange excess-demand theory as a false paradigm inapplicable to the Nigerian economy characterized by overwhelming dependence on crude-oil exports, excessive and inelastic demand for imports, terribly unfavorable investment environment, rapid inflation rate, severe political instability, and unbridled corruption all fuelling immense capital flight. The non-applicability of the theory was empirically established for Nigeria with graphical analysis (as shown in Fig.2 and Fig.3) and econometric analysis detailed in Appendix III. Various econometric model specifications were explored, which came to the same conclusion that foreignexchange excess demand is not negatively dependent on the exchange rate as expected by the foreign-exchange excessdemand theory. The paper also explored the impact of the exchange rate on demand for imports that are theoretically expected to be negative, but which turns out opposite for Nigeria. The regression of manufacturing sector output on exchange rate found that exchange rate did not at all promote output of manufactured goods as theoretically expected. The reasons for this failure include the heavy dependence of the manufacturing industries on imported plants and machinery and intermediate inputs, whose costs escalate with the rising exchange rate. Moreover, the industries face an extremely unfavorable 


\author{
Vol: 3, Issue: 2 \\ February/2022 \\ DOI: http://dx.doi.org/10.47742/ijbssr.v3n2p1 \\ https://ijbssrnet.com/index.php/ijbssr
}

investment environment of severely inadequate and high costs of income inelastic, and the political economy is characterized by energy and transportation infrastructure, political instability, and the rapid inflation rate, acute shortage of energy and terrible insecurity. This has adversely affected the transportation infrastructure, dreadful insecurity, severe political competitiveness of the sector resulting in secularly declining instability, and excessive corruption that fuels calamitous capital outputs from 2,544.14 billion USD in 1985 to 54.67 billion USD flight. deregulation of the foreign exchange market will be in 2019 , in spite of the fact that exchange $\mathrm{N} / \$$ kept rising counterproductive. It is therefore advisable to regulate the foreign substantially from 1985 to 2019.

exchange market to promote the importation of essential non-

In conclusion, as long as the country's exports are competitive goods and services required for social and physical dominated by primary commodities, import demand is price and infrastructure and industrial development.

\title{
REFERENCES
}

Baran, Paul (1975). The Political Economy of Neo-Colonialism. London, Heinemann.

Barbier, E. (1987) The Concept of Sustainable Economic Development, Environmental Conservation 14(2), 101-110

Bauer, Peter T. (1984). Reality and Rhetoric: Studies in the Economics of Development, London, Weidenfeld \& Nicolson.

Buchanan, M. (1954). Social choice, democracy, and free markets. Journal of Political Economy 62: 114-123.

Chang, Ha-Joon, (2002). Kicking Away the Ladder: Development Strategy in Historical Perspective, London, Anthem Press. Dasgupta, P. (2007) “The Idea of Sustainable Development” Sustainability Science 2(1), 5-11.

Friedman, M. (1957). A Theory of the Consumption Function. Princeton, N.J. National Bureau of Economic Research, Princeton University Press.

Galtung, J. (1972). A Structural Theory of Imperialism (PRIO Publication 27-1), JPR VIII (2), 81-117; Journal of Peace Research 2(1) 64-90.

Goulet, D. (1971). The Cruel Choice: A New Concept in the Theory of Development; New York, Athenaeum.

Griffin, K. \& Gurley, J. (1985). Radical analysis of imperialism, the Third World and the transition to socialism: A survey article, Journal of Economic Literature 23, 1089-1143.

Grindle M. S., Thomas, J, W. (1991). Public Choices and Public Policy Change: The Political Economy of Reform in Developing Countries. Baltimore, Johns Hopkins U.P.

Koyck, L. M. (1954). Distributed Lags and Investment Analysis. Amsterdam. North-Holland Publishing Company.

Kuznets, S. (1971). Economic Growth of Nations: Total Output and Production Structure; Cambridge MA, Belknap Press of Harvard University Press.

Kuznets, S. (1973). Modern Economic Growth: Findings and Reflections, American Economic Review 63 (Sept. 1973), $247-258$.

Lal, D. (1985). The Poverty of Development Economics, Cambridge, Mass., Harvard U.P.

Lewellen T. C. (1998). Dependency and Development: An Introduction to the Third World, Westport, Conn., Bergin \& Garvey.

Leys, C. (1975). Under development in Kenya: The Political Economy of Neo-colonialism, London, Heinemann.

Little, I., (1982). Economic Development: Theories, Policies and International Relations. New York, Basic Books.

Nerlove, Marc (1958). Distributed Lags and Demand Analysis for Agricultural and other Commodities, Agricultural Handbook No. 141. US Department of Agriculture.

Olagunju, T. E. (2015). Drought, Desertification and the Nigerian Environment: A review. Journal of Ecology and Natural Environment, vol. 7(7), 196-209.

Olutayo, A. O., Omobowale, A. O. (2007). Capitalism, Globalisation, and Underdevelopment Process in Africa: History in perpetuity. Africa Development 32(2).

Pearce, D., Markandya, A., and Barbier, E. (1989) Blueprint for a Green Economy, London, Earthscan.

Seers, D. (1969). The Meaning of Development. Eleventh World Conference of the Society for International Development, New Delhi.

Sen, A. (1985). Commodities and Capabilities; Amsterdam, North Holland.

Sen, A. (1999). Development as Freedom; New York, Alfred Knopf.

Singer, H. W. (1970). Dualism revisited: A new approach to the problem of dual societies in developing countries" Journal of Development Studies 7 (1970), 60-61. 


\author{
Vol: 3, Issue: 2 \\ February/2022 \\ DOI: http://dx.doi.org/10.47742/ijbssr.v3n2p1 \\ https://ijbssrnet.com/index.php/ijbssr
}

Syrquin, M., Taylor, L., Westphal, L. E. (eds.) (1984). Economic Structure and Performance: Essays in Honor of

Hollis B. Chenery; Orlando, Academy Press.

Tinbergen, J. (1960). Development Planning; Amsterdam; World University Library.

Tinbergen, J. (1978). Economic Policy: Principles and Design, Amsterdam, North Holland.

Todaro, M. P. \& Smith, S. C. (2015). Economic Development (12 ${ }^{\text {th }}$ edn). Addison-Wesley.

United Nations (1987) Report of the World Commission on Environment and Development; General Assembly Resolution 42/187; December 11, 1987.

UNDP (2011). The Human Development Report; New York.

UNDP (2019). The Human Development Report; New York.

Weisskopf, T. E. (1972). Capitalism, Underdevelopment, and the Future of the Poor Countries, Journal of Radical

Political Economics 4(1), 1-35.

World Bank (1991). World Development Report. Washington D.C. The World Bank.

hptts://www.data.worldbank.org 2019

hptts://www.fao.org/Oct. 10, 2020

\title{
APPENDIX I
}

\section{Econometric Model Formulations}

Five model formulations were explored where the dependent variable is Foreign Exchange Excess Demand, that is, Current Account Balance of Payments Deficit $(Y)$, while the explanatory variable is Exchange Rate $\mathrm{N} / \$(X)$. The formulations were derived as follows:

\section{(1) Simple Equation model}

Here, $Y$ is a simple function of the main explanatory variable, $\mathrm{X}_{1}$, given by:

$Y_{t}=\beta_{0}+\beta_{1} X_{1 t}+\mu_{t}$

$\beta_{0}>0, \beta_{1}<0$ are a-priori expectations of excess demand theory such that when exchange rate rises, excess demand for foreign exchange falls and when the exchange rate falls, excess demand for foreign exchange rises, implying a negative regression coefficient $\beta_{1}$.

(2) The Lag Distributed Model with current and lagged independent variables

The lag distributed model with lagged independent variables is where the dependent variable $Y$ is a function of current and lagged explanatory variable as follows:

$Y_{t}=\alpha_{0}+\beta_{0} X_{t}+\beta_{1} X_{t-1}+\beta_{2} X_{t-2}+\beta_{3} X_{t-3}+\ldots+\beta_{k} X_{t-k}+\mu_{t}$

A simple algebraic lag transformation proposed by Koyck (1954) assumes that the impact of lagged independent variable decreases geometrically with the lag, i.e.,

$$
\beta_{1}=\lambda \beta_{0}, \beta_{2}=\lambda^{2} \beta_{0}, \beta_{3}=\lambda^{3} \beta_{0}, \beta_{0}=\lambda^{k} \beta_{0}
$$

So (A.1) becomes:

$$
Y_{t} \quad=\alpha+\beta_{0} X_{t}+\lambda \beta_{0} X_{t-1}+\lambda^{2} \beta_{0} X_{t-2}+\lambda^{3} \beta_{0} X_{t-3}+\ldots+\lambda^{k} \beta_{0} X_{t-k}+\ldots+u_{t} ;
$$

Subtracting $\lambda Y_{t-1}$ from $Y_{t}$, cancelling out all $X$ terms with lags of $t-1$ to $t-k$, we have:

$Y_{t} \quad=\alpha^{*}+\beta_{0} X_{t}+\lambda Y_{t-1}+v_{t}$, where $\alpha^{*}=\alpha(1-\lambda), v_{t}=u_{t}-\lambda u_{t-1}$.

$\alpha^{*}>0, \beta_{0}<0,0<\lambda<1$ are the a-priori expectations of excess demand theory.

(3) The Partial Adjustment Model is reduced to the following form:

$$
Y_{t}=\beta_{0}+\beta_{1} Y_{t-1}+\beta_{2} X_{t}+u_{t}, 0<\beta_{1}<1, \beta_{2}<0 \text {, as a-priori expectations. (A.2) }
$$

The partial adjustment model is based on a concept of the desired value of a variable $\left(Y_{t}^{*}\right)$, which is dependent on the variable $X_{t}$, whose value is not yet known at time $t$, so that when the value of $X_{t}$ is known, the projected dependent variable $Y_{t}$ will be adjusted to the desired value $Y_{t}^{*}$ (see for example, Marc Nerlove, 1958). $Y_{t}^{*}$ is given by:

$$
\begin{aligned}
& Y_{t}^{*}=\alpha+\beta X_{t}+v_{t} \\
& \alpha>0, \beta<0 \text { are a-priori expectations of foreign exchange excess demand theory. }
\end{aligned}
$$

The econometric challenge is that the desired value $Y^{*}$ cannot be directly measured, but a technique can be adopted to predict the actual value, $Y$, that adjusts itself towards the desired level, $Y^{*}$, through an adjustment coefficient, $\lambda$, as follows: 


\title{
International Journal of Business and Social Science Research
}

\author{
Vol: 3, Issue: 2 \\ February/2022 \\ DOI: http://dx.doi.org/10.47742/ijbssr.v3n2p1 \\ https://ijbssrnet.com/index.php/ijbssr
}

$Y_{t}=Y_{t-1}+\lambda\left(Y_{t}^{*}-Y_{t-1}\right) ; 0<\lambda<1$

(A.4)

That is, the actual value $Y_{t}$ is adjusted towards the desired value $Y_{t}^{*}$ by improving on the previous actual value $Y_{t-1}$, partially closing the gap through the adjustment coefficient $\lambda$. We can then derive equation (A.2) by substituting equation (A.3) into (A.4) to obtain:

$$
\begin{aligned}
& \boldsymbol{Y}_{t}=\boldsymbol{\beta}_{0}+\boldsymbol{\beta}_{1} \boldsymbol{Y}_{t-1}+\boldsymbol{\beta}_{2} \boldsymbol{X}_{\boldsymbol{t}}+\boldsymbol{\mu}_{\boldsymbol{t}}, \\
& \beta_{0}=\alpha \lambda>0, \beta_{1}=1-\lambda>0, \beta_{2}=\beta \lambda<0, \text { are a-priori expectations of excess demand theory. }
\end{aligned}
$$

\section{(4) Adaptive expectation as applicable to market model}

This model assumes that the current price needs to be estimated by actors in the market before its actualization, based on the gap by which the actual price differs from the expected in the previous period, through an adaptation coefficient that reviews the estimate upwards or downwards according to whether the gap is positive or negative. The resultant regression equation is given by:

$$
\begin{aligned}
& Y_{t}=\beta_{0}+\beta_{1} X_{t-1}+\beta_{2} Y_{t-1}+\mu_{t} ; \text { where } \mu_{t} \text { is the disturbance term. (A.5) } \\
& \beta_{0}>0, \beta_{1}<0,0<\beta_{2}<1 \text { are a-priori expectations of excess demand theory. }
\end{aligned}
$$

The general principle of the Adaptive Expectations Model (see for example Friedman, 1957) is that the dependent variable is determined by expectations about the major explanatory variable. But the expectations may differ from the actual. So, the estimation is reviewed given the actual value of the explanatory variable. The model is given as:

$$
Y_{t}=\alpha+\beta X_{t}^{*}+\mu_{t} \text {; where } \mu_{t} \text { is the disturbance term. }
$$

$Y_{t}$ is dependent variable, $X_{t}^{*}$ is the expectation regarding $X_{t} ; \alpha>0$, and $\beta<0$ are a-priori expectations of excessdemand theory.

The adaptive expectation is that the gap by which the actual differs from the expected in the previous period will determine the change in the adjustment of the expectation for the current period. That is:

$$
\begin{aligned}
& X_{t}^{*}-X_{t-1}^{*}=\lambda\left(X_{t-1}-X_{t-1}^{*}\right) ; \lambda>0, \text { or } \\
& X_{t}^{*}=\lambda X_{t-1}+(1-\lambda) X_{t-1}^{*}
\end{aligned}
$$

From equation (A.6), we can write:

$$
X_{t}^{*}=\left(Y_{t}-\alpha-u_{t}\right) / \beta \text {, and } X_{t-1}^{*}=\left(Y_{t-1}-\alpha-u_{t-1}\right) / \beta \text {. }
$$

Substituting these values of $X_{t}^{*}$ and $X_{t-1}^{*}$ in equation (A.7), we have:

$$
\frac{Y_{t}-\alpha-u_{t}}{\beta}=\lambda X_{t-1}+(1-\lambda)\left(\frac{Y_{t-1}-\alpha-u_{t-1}}{\beta}\right)
$$

Simplifying the expression above, we have:

$$
\begin{array}{ll} 
& Y_{t}=\lambda \beta X_{t-1}+\alpha+u_{t}+(1-\lambda) Y_{t-1}-(1-\lambda) \alpha-(1-\lambda) u_{t-1} \\
\text { i.e. } \quad Y_{t}=\lambda \alpha+(1-\lambda) Y_{t-1}+\lambda \beta X_{t-1}+u_{t}-(1-\lambda) u_{t-1} \\
\text { i.e. } \quad Y_{t}=\beta_{0}+\beta_{1} X_{t-1}+\beta_{2} Y_{t-1}+v_{t} ; \quad \text { as presented in equation (A.5), } \\
\text { where } \beta_{0}=\lambda \alpha>0, \beta_{1}=\lambda \beta<0,0<\beta_{2}=(1-\lambda)<1, v_{t}=u_{t}-(1-\lambda) u_{t-1} .
\end{array}
$$

\section{(5) Dynamic (Cob-web) market model}

This model assumes that the demand (for foreign exchange) is a negative function of current price (exchange rate) and a positive function of current national income, while the supply (for foreign exchange) is a positive function of price lagged one period. The resultant regression equation is given by:

$Y_{t}=\beta_{0}+\beta_{1} X_{t}+\beta_{2} X_{t-1}+\beta_{3} Y_{t}+\mu_{t} ;$ where $\mu_{t}$ is disturbance term.

$\mathrm{B}_{0}>0, \beta_{1}<0$, and $\beta_{2}<0$ are a-priori expectations. $\beta_{3}$ can be positive or negative.

The Cob-web market model may be specified as follows:

$\mathrm{Q}_{\mathrm{d}, \mathrm{t}}=\mathrm{a}_{0}-\mathrm{a}_{1} \mathrm{P}_{\mathrm{t}}+\mathrm{a}_{2} \mathrm{Y}_{\mathrm{t}}+\mu_{1} ; \mathrm{a}_{0}>0, \mathrm{a}_{1}>0, \mathrm{a}_{2}>0$, and $\mu_{1}$ is disturbance term.

$\mathrm{Q}_{\mathrm{s}, \mathrm{t}}=-\mathrm{b}_{0}+\mathrm{b}_{1} \mathrm{P}_{\mathrm{t}-1}+\mathrm{b}_{2} \mathrm{Y}_{\mathrm{t}}+\mu_{2} ; \mathrm{b}_{0}>0, \mathrm{~b}_{1}>0, \mathrm{~b}_{2}>0$, and $\mu_{2}$ is disturbance term.

$\mathrm{Q}_{\mathrm{d}, \mathrm{t}}$ is quantity demanded (foreign exchange demand); $\mathrm{Q}_{\mathrm{s}, \mathrm{t}}$ is quantity supplied (foreign exchange supply); $\mathrm{P}_{\mathrm{t}}$ is price (exchange rate), and $\mathrm{Y}_{\mathrm{t}}$ is national income (GDP). It is to be noted that national income is added as an explanatory variable for quantity demanded and quantity supplied because foreign exchange demand for imported goods and services are financed from earnings from GDP while foreign exchange supply comes from exports that form part of GDP. From the equations of the market model above, foreign exchange excess demand (FXD) is given by:

i.e.

$$
\begin{aligned}
\mathrm{Q}_{\mathrm{d}, \mathrm{t}}-\mathrm{Q}_{\mathrm{s}, \mathrm{t}} & =\mathrm{a}_{0}-\mathrm{a}_{1} \mathrm{P}_{\mathrm{t}}+\mathrm{a}_{2} \mathrm{Y}_{\mathrm{t}}+\mu_{1}-\left(\mathrm{b}_{0}+\mathrm{b}_{1} \mathrm{P}_{\mathrm{t}-1}+\mathrm{b}_{2} \mathrm{Y}_{\mathrm{t}}-\mu_{2}\right) ; \\
& =\left(\mathrm{a}_{0}+\mathrm{b}_{0}\right)-\mathrm{a}_{1} \mathrm{P}_{\mathrm{t}}-\mathrm{b}_{1} \mathrm{P}_{\mathrm{t}-1}+\left(\mathrm{a}_{2}-\mathrm{b}_{2}\right) \mathrm{Y}_{\mathrm{t}}+\left(\mu_{1}-\mu_{2}\right)
\end{aligned}
$$

where $\beta_{0}=a_{0}+b_{0}, \beta_{1}=-a_{1}, \beta_{2}=-b_{1}, \beta_{3}=a_{2}-b_{2}$, and $\mu=\mu_{1}-\mu_{2}$ is disturbance term.

Thus, $\beta_{0}>0$. $\beta_{1}<0, \beta_{2}<0$, and $\beta_{3}\left(=a_{2}-b_{2}\right)$ may be positive or negative. 


\section{International Journal of Business and Social Science Research}

Vol: 3, Issue: 2

February/2022

DOI: http://dx.doi.org/10.47742/ijbssr.v3n2p1

https://ijbssrnet.com/index.php/ijbssr

\section{APPENDIX II \\ STATISTICAL TABLES}

\begin{tabular}{|c|c|c|c|c|c|c|c|c|c|}
\hline Year & $\begin{array}{c}\text { MNS } \\
(\$ b)\end{array}$ & $\begin{array}{c}X \\
(\$ b) \\
\end{array}$ & $\begin{array}{c}\text { FXD } \\
(-\mathrm{BOP})\end{array}$ & $\begin{array}{c}\text { EXR. } \\
\text { N/\$ }\end{array}$ & $\begin{array}{l}\text { MFQ } \\
(\$ \mathrm{~m})\end{array}$ & $\begin{array}{l}\mathrm{XNO} \\
(\$ \mathrm{~m})\end{array}$ & $\begin{array}{l}\text { GDP (Nb) } \\
\text { Nominal }\end{array}$ & $\begin{array}{l}\text { GDP } \\
(\$ b)\end{array}$ & PL \\
\hline 1981 & 24.06 & 18.07 & 5.99 & 0.61 & $2,555.14$ & 561.94 & 144.8 & 237.418 & 0.95 \\
\hline 1982 & 19.02 & 12.20 & 6.82 & 0.67 & $2,622.95$ & 301.99 & 155.0 & 230.326 & 1.03 \\
\hline 1983 & 14.30 & 10.36 & 3.94 & 0.72 & $1,612.79$ & 416.08 & 163.0 & 225.094 & 1.18 \\
\hline 1984 & 11.49 & 11.88 & -0.39 & 0.76 & $1,332.01$ & 323.42 & 170.4 & 222.733 & 1.24 \\
\hline 1985 & 10.38 & 13.11 & -2.74 & 0.89 & $1,585.22$ & 556.20 & 192.3 & 215.131 & 1.29 \\
\hline 1986 & 5.78 & 4.41 & 1.37 & 2.02 & 679.84 & 273.24 & 202.4 & 100.187 & 1.33 \\
\hline 1987 & 7.61 & 7.56 & 0.05 & 4.02 & 347.96 & 535.60 & 249.4 & 62.081 & 1.63 \\
\hline 1988 & 7.17 & 6.88 & 0.30 & 4.54 & 356.70 & 607.79 & 320.3 & 70.608 & 1.98 \\
\hline 1989 & 6.55 & 7.84 & -1.29 & 7.39 & 225.27 & 399.70 & 419.2 & 56.713 & 2.42 \\
\hline 1990 & 8.56 & 13.67 & -5.12 & 8.04 & 207.86 & 405.53 & 499.7 & 62.166 & 2.59 \\
\hline 1991 & 11.72 & 12.26 & -0.54 & 9.91 & 184.60 & 472.00 & 596.0 & 60.149 & 3.10 \\
\hline 1992 & 10.34 & 11.89 & -1.55 & 17.30 & 101.66 & 244.40 & 909.8 & 52.595 & 4.64 \\
\hline 1993 & 11.61 & 9.92 & 1.69 & 22.05 & 77.40 & 226.35 & $1,259.1$ & 57.098 & 6.32 \\
\hline 1994 & 9.27 & 9.42 & -0.14 & 21.89 & 76.34 & 244.40 & $1,762.8$ & 80.545 & 8.82 \\
\hline 1995 & 10.62 & 11.73 & -1.11 & 81.02 & 19.65 & 285.06 & $2,895.2$ & 35.733 & 14.22 \\
\hline 1996 & 9.05 & 16.12 & 7.06 & 81.25 & 19.69 & 287.10 & $3,779.1$ & 46.511 & 17.84 \\
\hline 1997 & 11.80 & 15.21 & -3.41 & 81.65 & 19.72 & 357.18 & $4,111.6$ & 50.357 & 18.87 \\
\hline 1998 & 11.45 & 8.97 & 2.48 & 83.81 & 16.85 & 406.53 & $4,589.0$ & 54.757 & 20.55 \\
\hline 1999 & 11.08 & 12.88 & -1.79 & 92.34 & 15.80 & 211.09 & $5,307.4$ & 57.475 & 23.64 \\
\hline 2000 & 10.18 & 19.12 & -8.94 & 101.77 & 14.79 & 243.90 & $6,897.5$ & 67.773 & 29.12 \\
\hline 2001 & 14.05 & 16.75 & -2.70 & 111.49 & 14.95 & 251.23 & $8,134.1$ & 72.960 & 32.19 \\
\hline 2002 & 13.67 & 14.46 & -0.78 & 120.65 & 15.03 & 785.16 & $11,332.3$ & 93.924 & 39.13 \\
\hline 2003 & 16.72 & 23.90 & -7.17 & 129.22 & 14.84 & 733.43 & $13,301.6$ & 102.935 & 41.95 \\
\hline 2004 & 17.57 & 34.61 & -17.04 & 133.00 & 16.12 & 851.94 & $17,321.3$ & 130.235 & 49.46 \\
\hline 2005 & 30.80 & 55.27 & -24.47 & 131.10 & 17.93 & 808.20 & $22,270.0$ & 169.870 & 59.43 \\
\hline 2006 & 33.91 & 57.16 & -23.25 & 128.14 & 20.09 & $1,042.55$ & $28,662.5$ & 223.677 & 71.66 \\
\hline 2007 & 45.58 & 66.44 & -20.86 & 20.86 & 22.58 & $1,593.22$ & ,995.4 & 263.824 & 76.87 \\
\hline 2008 & 62.35 & 88.65 & -26.30 & 26.30 & 26.14 & $4,481.49$ & $39,157.9$ & 332.460 & 85.10 \\
\hline 2009 & 47.78 & 58.18 & -10.39 & 147.27 & 22.57 & $3,396.88$ & $44,285.6$ & 300.706 & 88.83 \\
\hline 2010 & 29.69 & 80.58 & -50.89 & 148.31 & 24.13 & $4,773.30$ & $54,612.3$ & 368.230 & 100.00 \\
\hline 2011 & 88.14 & 99.88 & -11.74 & 151.83 & 27.77 & $5,988.06$ & $62,980.4$ & 414.817 & 109.51 \\
\hline 2012 & 79.11 & 96.90 & -17.79 & 155.45 & 30.77 & $5,630.58$ & $71,713.9$ & 461.331 & 119.66 \\
\hline 2013 & 74.87 & 97.82 & -22.95 & 155.25 & 37.53 & $7,243.54$ & $80,092.6$ & 515.882 & 126.69 \\
\hline 2014 & 84.46 & 82.60 & 1.86 & 156.48 & 42.71 & $6,080.49$ &, 043.6 & 569.024 & 132.60 \\
\hline 2015 & 68.79 & 45.89 & 22.90 & 191.80 & 34.34 & $3,444.35$ & $94,145.0$ & 490.841 & 136.39 \\
\hline 2016 & 43.25 & 34.70 & 8.55 & 253.09 & 35.18 & $2,674.86$ & $101,489.5$ & 400.998 & 149.40 \\
\hline 2017 & 45.90 & 54.87 & -8.96 & 305.29 & 32.90 & $4,215.93$ & $113,711.6$ & 372.471 & 166.02 \\
\hline 2018 & 66.82 & 72.53 & -5.71 & 305.58 & 40.76 & $5,527.74$ & $127,762.6$ & 418.095 & 183.01 \\
\hline 2019 & 95.87 & 76.75 & 19.12 & 306.42 & 54.67 & $12,362.24$ & $144,210.5$ & 469.818 & 202.01 \\
\hline
\end{tabular}

Source: CBN Statistical Bulletin 2020

MNS = Imports \& Net Services; $\mathrm{X}=$ Exports of Goods; $\mathrm{XNO}=$ Exports of Non-oil Products;

FXD = Foreign Exchange Excess Demand (-BOP); MFQ = Manufactured Sector Output;

EXR $=$ Exchange Rate N/ $;$ PL = General Price Level (GDP Deflator, 2010=100);

GDP Nominal $=$ GDP at Current Basic Prices; GDP $(\$ b)=$ GDP Nominal/Exchange Rate 


\section{International Journal of Business and Social Science Research}

Vol: 3, Issue: 2

February/2022

DOI: http://dx.doi.org/10.47742/ijbssr.v3n2p1

https://ijbssrnet.com/index.php/ijbssr

\section{APPENDIX III \\ REGRESSION EQUATIONS}

Equation 1: Consistent with simple equation, lag distribution, and partial adjustment model formulations (i), (ii), \& (iii)

Dependent Variable: FXD

Method: Least Squares

Sample(adjusted): 19822019

Included observations: 38 after adjusting endpoints

\begin{tabular}{ccccc}
\hline \hline Variable & Coefficient & Std. Error & t-Statistic & Prob. \\
\hline \hline C & -2.502490 & 2.973721 & -0.841535 & 0.4058 \\
EXR & -0.000745 & 0.022059 & -0.033751 & 0.9733 \\
FXD(-1) & 0.515014 & 0.155267 & 3.316964 & 0.0021 \\
\hline \hline R-squared & 0.246152 & Mean dependent var & -5.684211 \\
Adjusted R-squared & 0.203075 & S.D. dependent var & 13.15535 \\
Durbin-Watson stat & 2.041745 & Prob(F-statistic) & 0.007120
\end{tabular}

Equation 2: Consistent with Adaptive Expectation Model (iv)

Dependent Variable: FXD

Method: Least Squares

Sample(adjusted): 19822019

Included observations: 38 after adjusting endpoints

\begin{tabular}{ccccc}
\hline \hline Variable & Coefficient & Std. Error & t-Statistic & Prob. \\
\hline \hline C & -2.249435 & 2.913019 & -0.772201 & 0.4452 \\
EXR(-1) & -0.003863 & 0.023915 & -0.161541 & 0.8726 \\
FXD(-1) & 0.509119 & 0.158373 & 3.214677 & 0.0028 \\
\hline \hline R-squared & 0.246689 & Mean dependent var & -5.684211 \\
Adjusted R-squared & 0.203643 & S.D. dependent var & 13.15535 \\
Durbin-Watson stat & 2.026841 & Prob(F-statistic) & 0.007031
\end{tabular}

Dependent Variable: FXD

Method: Least Squares

Sample(adjusted): 19822019

Included observations: 38 after adjusting endpoints

\begin{tabular}{ccccc}
\hline \hline Variable & Coefficient & Std. Error & t-Statistic & Prob. \\
\hline \hline C & -3.551158 & 3.268238 & -1.086567 & 0.2851 \\
EXR & 0.094730 & 0.136158 & 0.695738 & 0.4915 \\
EXR(-1) & -0.119390 & 0.147538 & -0.809216 & 0.4242 \\
GDP\$ & 0.010941 & 0.016944 & 0.645696 & 0.5229 \\
FXD(-1) & 0.474925 & 0.185696 & 2.557537 & 0.0153 \\
\hline \hline R-squared & 0.268411 & Mean dependent var & -5.684211 \\
Adjusted R-squared & 0.179734 & S.D. dependent var & 13.15535 \\
Durbin-Watson stat & 1.941383 & Prob(F-statistic) & 0.031269
\end{tabular}




\section{International Journal of Business and Social Science Research}

Vol: 3, Issue: 2

February/2022

DOI: http://dx.doi.org/10.47742/ijbssr.v3n2p1

https://ijbssrnet.com/index.php/ijbssr

\section{Additional Significant Regression Equations}

Dependent Variable: MNS

Method: Least Squares

Sample: 19812019

Included observations: 39

\begin{tabular}{ccccc}
\hline \hline Variable & Coefficient & Std. Error & t-Statistic & Prob. \\
\hline \hline C & -23.85933 & 6.565492 & -3.634051 & 0.0009 \\
REXR & 0.063801 & 0.017557 & 3.634030 & 0.0009 \\
GDP\$ & 0.186908 & 0.013437 & 13.90984 & 0.0000 \\
\hline \hline R-squared & 0.881711 & Mean dependent var & 30.29154 \\
Adjusted R-squared & 0.875140 & S.D. dependent var & 27.31239 \\
Durbin-Watson stat & 1.579854 & Prob(F-statistic) & 0.000000
\end{tabular}

Dependent Variable: MFQ\$

Method: Least Squares

Sample(adjusted): 19822019

Included observations: 38 after adjusting endpoints

\begin{tabular}{ccccc}
\hline \hline Variable & Coefficient & Std. Error & t-Statistic & Prob. \\
\hline \hline C & -0.451398 & 3.851744 & -0.117193 & 0.9074 \\
EXR & 0.004667 & 0.025603 & 0.182275 & 0.8564 \\
MFQ\$(-1) & 0.799437 & 0.053261 & 15.00968 & 0.0000 \\
\hline \hline R-squared & 0.896455 & Mean dependent var & 16.68053 \\
Adjusted R-squared & 0.890538 & S.D. dependent var & 35.91154 \\
Durbin-Watson stat & 2.523695 & Prob(F-statistic) & 0.000000 \\
& \multicolumn{5}{c}{} \\
& Dependent Variable: FXD \\
\hline \multicolumn{5}{c}{ Method: Least Squares } \\
Sample: 1981 2019 & \\
\hline \hline Included observations: 39 & \\
Variable & Coefficient & Std. Error & t-Statistic & Prob. \\
EXIL & 4.288843 & 3.650004 & 1.175024 & 0.2477 \\
EXR & -0.263659 & 0.077336 & -3.409267 & 0.0016 \\
R-squared & 0.036707 & 0.026435 & 1.388580 & 0.1735 \\
\hline \hline Adjusted R-squared & 0.254818 & Mean dependent var & -5.384872 \\
Durbin-Watson stat & 0.213419 & S.D. dependent var & 13.11501 \\
& 1.280126 & Prob(F-statistic) & 0.005020
\end{tabular}

Dependent Variable: BOP

Method: Least Squares

Sample(adjusted): 19822019

Included observations: 38 after adjusting endpoints

\begin{tabular}{ccccc}
\hline \hline Variable & Coefficient & Std. Error & t-Statistic & Prob. \\
\hline \hline C & 2.502490 & 2.973721 & 0.841535 & 0.4058 \\
EXR & 0.000745 & 0.022059 & 0.033751 & 0.9733 \\
BOP(-1) & 0.515014 & 0.155267 & 3.316964 & 0.0021 \\
\hline \hline R-squared & 0.246152 & Mean dependent var & 5.684211 \\
Adjusted R-squared & 0.203075 & S.D. dependent var & 13.15535 \\
Durbin-Watson stat & 2.041745 & Prob(F-statistic) & 0.007120
\end{tabular}

